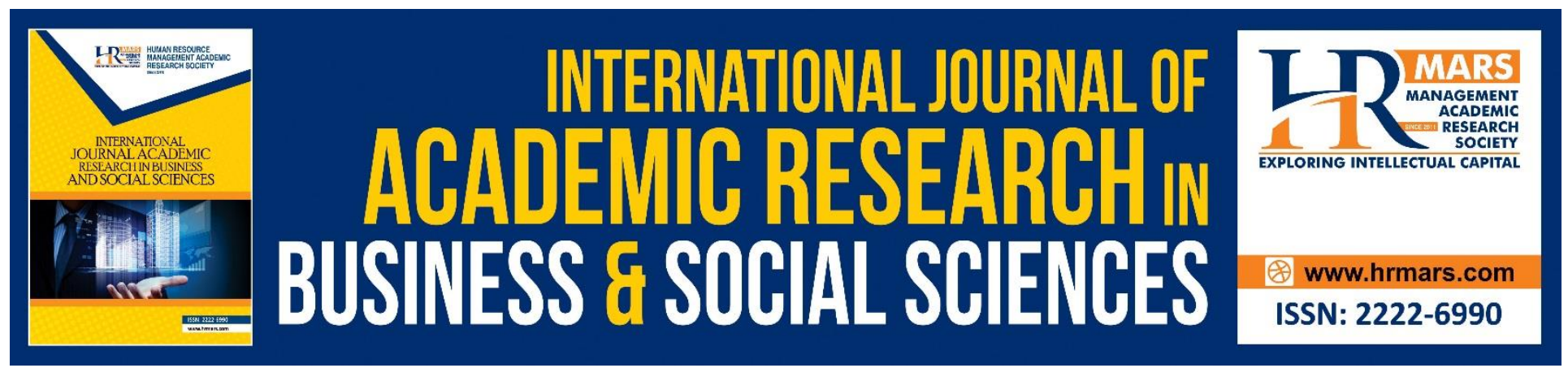

\title{
The Use of Qawl Muktamad (Final Opinion) in Syafi'i School in the Fatwas: The Analysis of the Fatwa Committee of Negeri Sembilan
}

\section{Muhammad Alif Md Aris \& Wan Mohd Khairul Firdaus Wan Khairuldin}

To Link this Article: http://dx.doi.org/10.6007/IJARBSS/v10-i9/7891

DOI:10.6007/IJARBSS/v10-i9/7891

Received: 08 June 2020, Revised: 11 July 2020, Accepted: 15 August 2020

Published Online: 28 September 2020

In-Text Citation: (Aris, \& Khairuldin, 2020)

To Cite this Article: Aris, M. A.M., \& Khairuldin, W. M. K. F. W. (2020). The Use of Qawl Muktamad (Final Opinion) in Syafi'i School in the Fatwas: The Analysis of the Fatwa Committee of Negeri Sembilan. International Journal of Academic Research in Business and Social Sciences. 10(9), 981-987.

Copyright: (C) 2020 The Author(s)

Published by Human Resource Management Academic Research Society (www.hrmars.com)

This article is published under the Creative Commons Attribution (CC BY 4.0) license. Anyone may reproduce, distribute, translate and create derivative works of this article (for both commercial and non-commercial purposes), subject to full attribution to the original publication and authors. The full terms of this license may be seen

at: http://creativecommons.org/licences/by/4.0/legalcode

Vol. 10, No. 9, 2020, Pg. 981 - 987

http://hrmars.com/index.php/pages/detail/IJARBSS

JOURNAL HOMEPAGE

Full Terms \& Conditions of access and use can be found at http://hrmars.com/index.php/pages/detail/publication-ethics 


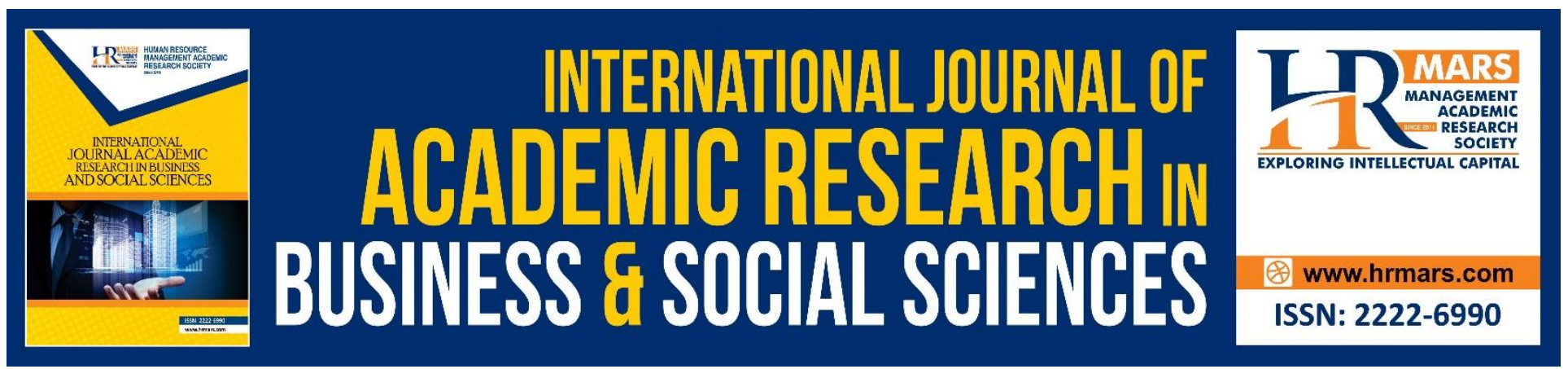

\title{
The Use of Qawl Muktamad (Final Opinion) in Syafi'i School in the Fatwas: The Analysis of the Fatwa Committee of Negeri Sembilan
}

\section{Muhammad Alif Md Aris \& Wan Mohd Khairul Firdaus Wan Khairuldin}

Faculty of Islamic Contemporary Studies, Universiti Sultan Zainal Abidin, Gong Badak Campus, 21300 Kuala Terengganu, Terengganu.

Email: aliefaris10@gmail.com

\begin{abstract}
Syafi'i school is the main school practiced by the Muslim community in Malaysia. The practice of Mazhab Syafi'i not only involves individual practice, but the final opinion of Syafi'i School is recognized as a priority view in the enactment of Islamic law throughout Malaysia except Perlis. The question is, does the use of the final opinion of Syafi'i School apply in all fatwas? Or a mixture of views is also used in determining the fatwa? To answer the question, this study tries to analyze the use of the final opinion of Syafi'i school in fatwas decided by the Fatwa Committee of Negeri Sembilan (JKFNS). This paper uses the documentation method as a data collection method. The fatwas analyzed are a total of 18 fatwas from the scope of worship only. This is because the fatwa of worship is the fatwa most decided by JKFNS. The data were then analyzed using content analysis methods. The study found that JKFNS prioritizes the qawl muktamad (final opinion) of the Syafi'i School in determining its fatwa even though there are some fatwas that are decided based on the external views of the Syafi'i school.
\end{abstract}

Keywords: Qawl Muktamad, Final Opinion, Syafi'i Scholl, Negeri Sembilan, Fatwas.

\section{Introduction}

Islam is the official religion practiced in Malaysia. Islam has long been established in Malaysia. There are many theories about the advent of Islam in the archipelago that have been discussed by scholars since the 1960s (Noor, 2011: 30). Islam believed to have reached the archipelago in the eleventh century through preachers from Parsi, India and Arabian (Ahmad, 2007: 41).

Since the beginning of the advent of Islam in the archipelago, the Syafi'i school is the earliest sect introduced and has firmly established (Majid, 2003: 3). The development and establishment of the Syafi'i School in this country is in line with the development of Islam in the region as a result of the 
INTERNATIONAL JOURNAL OF ACADEMIC RESEARCH IN BUSINESS AND SOCIAL SCIENCES Vol. 10, No. 9, 2020, E-ISSN: 2222-6990 @ 2020 HRMARS

efforts of the missionaries who came here and this is a history to be proud of because it has changed the region to the Islamic region ('Abdullah \& Jihatea, 2007: 104).

In addition, the Syafi'i School has fully mastered the field of law and practice for the whole archipelago from the beginning of the advent of Islam until under the Kingdom of Melaka which inherited the power of Islamic governments in the archipelago before that and the same thing happened under the influence of Islamic governments in the archipelago after that (Majid, 2007: 6).

Although the Syafi'i school is the main school in the determination of law in Malaysia, not all states practice the Syafi'i school in their enactment. In Malaysia, the existence of different methodologies in deducing fatwas and differences in these methodologies can be seen in the enactment provisions between the state of Perlis and other states (Rosele et al., 2013). According to 'Abdullah and Jihatea (2007), all states in Malaysia adopt the Syafi'i School in deciding state fatwas except the Perlis State Shariah Committee based on Ahli al-Sunnah wa al-Jama'ah without being bound by any school. and the source of the law is also different.

"The Negeri Sembilan Fatwa Committee (JFKNS) also adopted the Syafi'i sect in their fatwa. This is clearly illustrated in the Administration of the Religion of Islam (Negeri Sembilan) Enactment 2003 as stated in section 54:

“(1) In issuing any fatwa under section 49, or certifying an opinion under section 53 , the Fatwa Committee shall generally follow the final opinion (qawl muktamad) Syafi'i school.

(2) If the Fatwa Committee is of the opinion that by following the final opinion of the Syafi' $i$ school, a situation contrary to the public interest will result, the Fatwa Committee may follow the final opinion of the Hanafi, Maliki or Hanbali Schools.

(3) If the Fatwa Committee is of the opinion that none of the final opinion of the four sects can be followed without leading to a situation contrary to the public interest, the Fatwa Committee may make the fatwa according to ijtihad without being bound by the final opinion of any of the four sects."

As stated in the previous section 54, the final opinion of the Syafi'i school is the main view that prioritizes fatwa before turning to the views in other sects according to public interest. The question is, is this enactment practiced by JKFNS in deciding their fatwa? To answer this question, this study analyzes the use of the Qawl Muktamad (final opinion) of Syafi'i School in worship fatwas by the Fatwa Committee of Negeri Sembilan.

\section{Methodology}

This study uses the method of document analysis to get a clear picture of the position of the final opinion of Syafi'i School in the fatwas of JKFNS. The data were taken from a collection of JKFNS fatwas from 1994 to 2015. Only 18 fatwas involving public worship were analyzed out of a total of 79 fatwas. This document analysis method is also used in collecting data related to the concept of the final opinion of Syafi'i School. According to Jasmi (2012), the method of analyzing this document is used to obtain clear information in understanding a concept, issue and problem about a phenomenon that occurs. 
INTERNATIONAL JOURNAL OF ACADEMIC RESEARCH IN BUSINESS AND SOCIAL SCIENCES Vol. 10, No. 9, 2020, E-ISSN: 2222-6990 @ 2020 HRMARS

Next, the results of the data collection will be analyzed using content analysis methods. Content analysis is used to examine and explain the interpretations contained in the document. According to Krippendorff (2004: 18) and Yusof (2004: 34), content analysis is a research technique by making systematic and objective conclusions through document-shaped data. While Marican (2005: 170) and Lebar (2009: 146) define content analysis as an explanation that systematically examines a textual content in the form of text. This coincides with the data collected from the fatwas which are then analyzed to see the use of the final opinion of the Syafi'i School.

\section{Findings}

This study divides the findings of the study into two main discussions. First, the concept of the final opinion of the Syafi'i School. Second, the analysis of the use of the final opinion of the Syafi'i School in worship fatwas by the Negeri Sembilan Fatwa Committee.

\section{Qawl Muktamad (Final Opinion) of Syafi'i School}

Originally in the Syafi'i School, there is no specific use and meaning of the term for this final opinion ('Umar, 2008). Even the works of mutaqaddim Mazhab Syafi'i also do not use this term. However, according to 'Umar (2008); al-Anșari (d. 926H) was the first scholar to pioneer the use of this qawl muktamad (final opinion) around the 10th century $\mathrm{AH}$. This is as quoted in his book entitled Fath alWahab ala Sharh Minhaj al-Tullab. However, his disciple al-Haytami (d. 973H) was the first to give special meaning in terms of the qawl muktamad in the preface of the book Tuhfah al-Muhtaj li Sharh al-Minhaj.

The qawl muktamad on the side of Syafi'iyyah is the translated view and is the ijtihad of Imam alSyafi'i (m. 204H) from all his views, or the views arising from his valid rules and proposals backing up to his sect and it is common to issue fatwas, punish and follow them for the followers of his sect (alZuhaili, 2010). From the source perspective, the qawl muktamad in the Syafi'i School can be categorized into two categories namely the qawl muktamad sourced from Imam al-Syafi'i (d. 204H) and the qawl muktamad sourced from Așhab Syafi'i (Syafi'i's Scholar).

The qawl muktamad sourced from Imam al-Syafi'i (d. 204H) has two forms namely al-azhhar and almasyhūr. Among the books used as a reference to see the views of Imam al-Syafi'i (d. $204 \mathrm{H}$ ) is the book of al-Umm. While the qawl muktamad sourced from Așhab Syafi'i also has two forms namely al-așah and al-sahih. According to the scholars, the qawl muktamad of among mutaqaddimin is the opinion translated by al-Nawawi (d. 676H) and al-Rafi'i (m. 623H) (Sulaiman, 2008: 290). In addition, what Ibn Hajr (d. 973H) and al-Ramli (d. 1004H) agreed on problems that have never been discussed before them, then it is also considered as the qawl muktamad that they are from among the Contemporary Scholars of Syafi'i School (Ahmad, 2008: 39).

If there is a disagreement between al-Nawawi (d. 676H) and al-Rafi'i (d. 623H), then the view of alNawawi (d. 676H) comes first. It is also obligatory to issue a fatwa with all opinions from both (Ahmad, 2008: 39). When the views of al-Nawawi (d. 676H) collide with his views from other sources of his writings then his book according to the final order in the school is al-Tahqiq, followed by al-Majmū 'Sharh al-Muhadhab, followed by al-Tanqih, followed by Rawdah al-Talibin followed by Minhaj alṬalibin, followed by al-Minhaj Sharḥ Șaḥiḥ Muslim and finally Taṣhịh al-Tanbih (al-Saqaf, 2004: 73). 
INTERNATIONAL JOURNAL OF ACADEMIC RESEARCH IN BUSINESS AND SOCIAL SCIENCES Vol. 10, No. 9, 2020, E-ISSN: 2222-6990 @ 2020 HRMARS

According to al-Saqaf (2004), the qawl muktamad sequence of the Syafi' School is the view translated by Ibn Hajr (d. 973H) and al-Ramli (m. 1004H). Most Egyptian scholars adhere to the view expressed by al-Ramli (m. 1004H) in his book Nihayah al-Muhtaj li Sharh al-Minhaj. This book has been read to almost four hundred Syafi'i scholars as well as streamlined and criticized by them. This book has reached the limit of mutawatir in the truth of the content of the Shafii School. For the scholars of Hadharamaut, Syam and Hijaz, the ultimate opinion is what was issued by Imam Ibn Hajr al-Haytami (d. $973 \mathrm{H}$ ) through his book Tuhfah al-Muhtaj li Sharh al-Minhaj.

These views in the Syafi'i School have been perfectly refined by al-Nawawi (d. 676H) and al-Rafi'i ( $m$. $623 \mathrm{H})$. Then his debates were further strengthened at the hands of Ibn Hajr (d. $973 \mathrm{H}$ ) and al-Ramli (m. 1004H). So the scholars of muta'akhirin allowed their views to be used as fatwas. If there is a clash between the qawl muktamad of muta'akhirin which is a clash in the book of Nihayah and Tuhfah on a problem that cannot be translated, then the final one in the school on the issue of fatwa is the view chosen by al-Anșari (m. 926H ) through his book Syarh al-Bahjah al-Ṣaghir, then his book alManhaj wa Sharhah. Next comes the opinion of al-Khatib al-Sharbini (d. 977H). Then what Așhab alHawashi (hashiyyah figures) chose (al-Saqaf, 2004: 73).

Therefore, in deciding the fatwa in the framework of the qawl muktamad of Syafi'i School, every fatwa institution should be concerned about this sequence. According to al-Kurdi (2011), if any mufti makes a fatwa by putting the qawl dhaif (weak opinion) ahead of qawl muktamad in Syafi'i School, then it is not allowed. This is because this weak opinion is the opposite of the qawl muktamad and everything that is contrary to the qawl muktamad is usually a shortcoming that needs to be left out. The obligation to do good deeds with this poor qawl is only for oneself and not spread among the general public.

\section{The Analysis of the Use of the qawl muktamad of the Syafi'i School in the Fatwas of Worship by the Fatwa Committee of Negeri Sembilan}

Overall, there are 12 fatwas whose decisions are decided according to the qawl muktamad of Shafii School. Of the 12 fatwas, a total of four fatwas were gazetted. The remaining eight pieces are from fatwas that have not been gazetted.

Next, there are two fatwas that are decided by taking the opinion of Imam al-Syafi'i (d. 204H) and alNawawi (m. 676H). The decision of the fatwa related to "Money Loan Scheme From Cooperatives And The Like To Perform Fardu Hajj Or Umrah" is a decision taken based on the opinion of Imam alShafii (m. 204H). The opinion of al-Nawawi (d. 676H) is taken and accepted in matters related to "Jama 'Prayer for Undergoing the Treatment of Chronic Diseases in Government / Private Hospitals" is a decision taken based on opinion.

In addition, there is a fatwa whose decision is based on the opinion in the Hanafi School which is related to "Giving Zakat to Non-Muslims for the Purpose of Da'wah".

However, there are three fatwas whose sentence was decided based on the ijtihad of contemporary scholars and the fatwa committee. This is because the questions raised involve the latest issues. Acceptance of opinions other than the qawl muktamad of the Syafi'i School by choosing the opinions 
INTERNATIONAL JOURNAL OF ACADEMIC RESEARCH IN BUSINESS AND SOCIAL SCIENCES

Vol. 10, No. 9, 2020, E-ISSN: 2222-6990 @ 2020 HRMARS

of the other three secular schools, namely the Hanafi School or Maliki or Hanbali on an issue is to safeguard the welfare of society. This benefit is determined by the Fatwa Committee Member during the muzakarah which takes place once a month1

\section{Discussion}

Based on the analysis conducted, as many as $66 \%$ of the fatwa results are sourced from the qawl muktamad of the Syafi'i School. While as much as $11 \%$ are the opinions of Imam al-Syafi'i (d. 204H) and al-Nawawi (m. 676H). Next, the remaining $17 \%$ is the current ijitihad which consists of the opinion of contemporary scholars and the fatwa committee. The remaining $6 \%$ is a fatwa according to the Hanafi School.

It is clear here that the Negeri Sembilan Fatwa Committee performs their duties in accordance with the provisions enshrined in the Administration of the Religion of Islam (Negeri Sembilan) Enactment 2003, Section 54 (1). Every fatwa decision issued must be sourced from the qawl muktamad of the Syafi'i School, then look at the qawl muktamad of other sects namely Hanafi, Maliki and Hanbali. Even the fatwa committee is allowed to do ijtihad if there is no decision from these four mu'tabar sects.

The attachment of the fatwa institution to the qawl muktamad of the Syafi'i School and still adopting the opinion of other schools of figh in issuing fatwa decisions is an openness approach that gives birth to the nature of tolerance and harmony in Islam. This proves that Islam is a religion with the concept of Rahmatan lil-'alamin (A mercy to all creation) and is suitable to be practiced from time to time.

\section{Conclusion}

In conclusion, the results were analyzed in all 18 fatwas, so there are some six fatwas that do not follow the qawl muktamad of the Syafi' i School. It can be concluded that there are a total of 12 fatwas submitted sourced from the qawl muktamad of the Syafi'i School, two fatwas not sourced from the final qawl and four fatwas resulting from ijtihad.

\section{Acknowledgement}

Special thanks go to the Center for Research Excellence and Incubation Management (CREIM), Universiti Sultan Zainal Abidin for supporting this research.

\section{References}

Noor, A. M. (2011). Perkembangan Pensejarahan Islam Di Alam Melayu, Jurnal Tamadun. 2011 (6). al-Kurdi, M. S. (2011). al-Fawaid al-Madaniyyah. Damsyik: Dar Nur al- Șabaḥ.

Aḥmad, H. (2003). Taqrirat al-Sadidah fi al-Masa'il al-Mufidah. Hadharamaut: Dar al-Mirath alNabawiyyah.

al-Saqaf, A. A. (2004). Mukhtașar al-Fawaid al-Makkiyyah fi ma Yaḥtaju Ṭalabah al-Shafi'iyyah. Beirut: Dar al-Bashar al-Islamiyyah.

Ahmad, M. Y. (2007). Tamadun Islam. Kuala Lumpur: Penerbit Universiti Malaya.

Majid, M. Z. A. (2007). Mazhab Shafii di Malaysia: Sejarah, Realiti dan Prospek Masa Depan, Jurnal Fiqh. 4 (2007).

Sulaiman, A. (2008). al-Nahju al-Aqwa fi Arkan al-Fatwa. Riyadh: Dar al-'Asimah. 
INTERNATIONAL JOURNAL OF ACADEMIC RESEARCH IN BUSINESS AND SOCIAL SCIENCES

Vol. 10, No. 9, 2020, E-ISSN: 2222-6990 @ 2020 HRMARS

Abdullah, L., \& Jihatea, N. (2007). Bermazhab Dan Fanatik Mazhab: Satu Sorotan Dalam Kerangka Amalan Bermazhab Shafii Masyarakat Melayu, Jurnal Fiqh. 4 (2007).

Khairuldin, W. M. K. F. W., Embong, A. H., Hassan, S. A., Yasin, M. F. M., \& Anas, W. N. I. W. N. (2019). Strategic Management in Fatwa-making Process. Academy of Strategic Management Journal, 18(4), pp. 1-6.

Khairuldin, W. M. K. F. W., Anas, W. N. I. W .N., Embong, A. H., Ismail, D., \& Hanapi, M. S. (2019). The Challenges of Fatwa Institutions in Malaysia in Facing the Progress of Science and Technology, International Journal of Mechanical Engineering and Technology, 10(3), 2019, pp. 1806-1813.

Khairuldin, W. M. K. F. W., Anas, W. N. I. W. N., \& Embong, A. H. (2018). Experts' View within Fatwa Production in Malaysia. International Journal of Academic Research in Business and Social Sciences, 8(11), 530-538.

Khairuldin, W. M. K. F. W. (2017). Towards The Development of Islamic-based Research Methodology. International Journal of Academic Research in Business and Social Sciences. 7(2). pp. 450-457. [Indexed by: ERA - Main Author]

Khairuldin, W. M. K. F. W., \& Ibrahim, I. (2017). The Construction of Research Method Based on Fatwa Process: The Analysis from the Views of Expert. International Journal of Academic Research in Business and Social Sciences. 7(4). pp. 58-69. [Indexed by: ERA - Main Author] 